This is a self-archived version of an original article. This version may differ from the original in pagination and typographic details.

Author(s): Immanen, Mikko

Title: Days of the Cavemen? : Adorno, Spengler, and the Anatomy of Caesarism

Year: 2021

Version: Accepted version (Final draft)

Copyright: @ 2021 New German Critique, Inc

Rights: In Copyright

Rights url: http://rightsstatements.org/page//nC/1.0/?language=en

Please cite the original version:

Immanen, M. (2021). Days of the Cavemen? : Adorno, Spengler, and the Anatomy of Caesarism. New German Critique, 48(2), 177-204. https://doi.org/10.1215/0094033X-8989316 
Author's accepted manuscript: please cite the published version:

New German Critique 143, Vol. 48, No. 2 (August 2021): 177-204.

doi.org/10.1215/0094033X-8989316 (C) 2021 by New German Critique, Inc.

\title{
Days of the Cavemen? Adorno, Spengler, and the Anatomy of Caesarism
}

\author{
Mikko Immanen
}

Spengler sees something of the dual character of enlightenment in the era of universal domination. -Theodor W. Adorno, "Spengler after the Decline" (1950)

I hope that the elaboration of Spengler [essay] means a real preparatory work for our things.

-Theodor W. Adorno to Max Horkheimer (1941)

The Weimar Republic is often said to have lacked republicans. But surely this is an overstatement. Leading intellectuals of the time, such as the Kantian philosopher Ernst Cassirer, actively voiced their support for Germany's first democratic experiment. Yet in hindsight critics have pointed out that Cassirer and his like were unsuccessful because their trust in reason and progress was ill-equipped to face harsher postwar realities and mounting antidemocratic sentiment fed by new radical voices. Commenting on Cassirer's legendary 1929 Davos disputation with the iconoclastic existentialist, Martin Heidegger, Leo Strauss noted the contrast between the erudite but non-charismatic Cassirer and Heidegger who "gave adequate expression to the prevailing unrest and dissatisfaction."1

\footnotetext{
${ }^{1}$ Strauss, "Kurt Riezler," 246. All translations are mine unless otherwise indicated.
} 
Similarly, commemorating the seventieth birthday of Oswald Spengler in 1950, the Frankfurt School thinker Theodor W. Adorno claimed that among his Weimar-era critics Spengler "found hardly an adversary who was his equal." In his best-selling The Decline of the West (Der Untergang des Abendlandes), published in two volumes in 1918 and 1922, Spengler had famously envisioned for Europe the fate reserved for all "great cultures": withering away of creative energies of Kultur and rise of a shallow civilization of Nietzsche's "last man." ${ }^{2}$ Looking back at the Weimar academics' attacks on Spengler, Adorno concluded that "German mind collapsed when faced with an opponent who seemed to have inherited all the historical force of its own past." ${ }^{3}$

Adorno's comment was a reference to prestigious philosophical journal, Logos, which in 1920 had gathered an illustrious group of scholars to demolish the first volume of Spengler's book. ${ }^{4}$ Notwithstanding the political gulf between Adorno (1903-1969) and Spengler (1880-1936), Adorno would have none of the "pedantic punctiliousness" and "rhetoric of conformist optimism" of these condescending attacks. For Adorno and Strauss, both Jewish exiles from Nazi Germany, Weimar academics' inability to challenge popular and charismatic critics of reason had consequences far surpassing the university. "Led politically by Hitler and intellectually by Heidegger," Strauss concluded, "Germany entered the Third Reich." The weakness of Spengler's critics, Adorno contended, echoed "the political impotence of the Weimar Republic faced with Hitler."

\footnotetext{
${ }^{2}$ Spengler, The Decline of the West, Vol. I: Form and Actuality; Spengler, The Decline of the West, Vol. II: Perspectives of World History.

3 Adorno, "Spengler after the Decline," 54. First published in 1950 as "Spengler nach dem Untergang."

4 "Spenglerheft."

${ }^{5}$ Strauss, "Kurt Riezler," 241; Adorno, "Spengler after the Decline," 54.
} 
Adorno's view of Spengler was always ambiguous. He was adamant that the fact of the Holocaust alone made supercilious dismissals of Spengler highly dubious. Yet he refused the label of Spenglerian, insisting in his famous criticism of Adenauerian history politics that "do not mistake my fragmentary and often rhapsodic remarks for Spenglerism." ${ }^{6}$ Speaking against Spengler in the Germany of the 1950s Adorno saw the economic miracle and general recovery of the social fabric. Given these criticisms, one wonders why Adorno chose to cast the Logos authors in such a negative light. For surely he agreed on the urgency to criticize Spengler's book, which made authoritative and influential claims about the past, and, moreover, not only described the Zeitgeist of the 1920s but played into the hands of anti-republican and anti-socialist forces of Weimar Germany. As Adorno himself underscored: "Spengler and his like are not so much prophets of the course the Weltgeist will take as its diligent promoters."

How should we interpret this ambivalence? Adorno's writings on Spengler are few; accompanying "Spengler after the Decline" is a shorter piece from 1955 and scattered remarks here and there. ${ }^{8}$ Adorno's comments vacillate between harsh denouncements and unexpected praises. The latter should not come as a surprise. Although Adorno abhorred Spengler's Proto-Fascist worldview, considering Spengler's Europeanwide, even global impact it is small wonder that Adorno too found it worthwhile to engage with his ideas. ${ }^{9}$ I would like to suggest, however, that there is a more specific, dialec-

\footnotetext{
${ }^{6}$ Adorno, "The Meaning of Working Through the Past," 99.

${ }^{7}$ Adorno, "Spengler after the Decline," 66.

${ }^{8}$ Adorno, "Was Spengler Right?" First published in 1955 as "Wird Spengler recht behalten?"

${ }^{9}$ On Spengler's impact, see Merlio and Meyer eds., Spengler ohne Ende; Gasimov and Lemke Duque eds., Oswald Spengler als europäisches Phänomen.
} 
tical logic to Adorno's vacillation. The following passage from Minima Moralia (1951) offers a fine hermeneutic clue to make sense of this logic: "Not least among the tasks now confronting thought is that of placing all the reactionary arguments against Western culture in the service of progressive enlightenment." ${ }^{10}$ My proposition is that Adorno's contestation with Spengler formed a major instance of his effort to repurpose right-wing Zivilisationskritik for left-wing ends. The vexed question of the presence of elements from radical right-wing critique of reason in Adorno's thought-dominated by critical Marxism, aesthetic modernism, psychoanalysis, and Jewish tradition ${ }^{11}$ - has preoccupied scholars sporadically since the 1980s and the dispute over Carl Schmitt's influence on the Frankfurt School, claims that Adorno shared something of Walter Benjamin's fascination with Ludwig Klages's vitalist critique of reason, and Hermann Mörchen's study on the affinities between Adorno and Heidegger. ${ }^{12}$ Yet Spengler's case remains largely uncharted, as George Friedman and David Roberts are the only ones to discuss it in any detail. ${ }^{13}$

I begin by showing that what Adorno found intriguing in Spengler's Decline was its analysis of "Caesarism" of post-World War I Europe- "tendencies inherent in democracy which threaten to turn it into dictatorship."14 Adorno's interest in Decline, however, predates his wish to give Spengler's analysis its due in the Adenauerian Germany struggling to "come to terms with the past." By going back to the article's original 1941 version, I

\footnotetext{
${ }^{10}$ Adorno, Minima Moralia, 192.

${ }^{11}$ Jay, Adorno, 17-19. On right-wing Zivilisationskritik in interwar Germany, see Woods, The Conservative Revolution; Jeffrey Herf, Reactionary Modernism.

12 "Special Section on Carl Schmitt and the Frankfurt School”; Honneth, "Anthropologische Berührungspunkte"; Mörchen, Adorno und Heidegger. On Adorno and Heidegger more recently, see Gordon, Adorno and Existence; Immanen, Toward a Concrete Philosophy.

${ }^{13}$ Friedman, The Political Philosophy of the Frankfurt School, 79-86; Roberts, Art and Enlightenment, 73-81.

${ }^{14}$ Adorno, "Spengler after the Decline," 55.
} 
trace Adorno's interest in Spengler back to his New York exile in 1938-1941, when he took notice of the affinities between Spengler's analysis of "Caesarism" and Friedrich Pollock's thesis on "state capitalism." Moreover, given the appreciation of Spengler by both Adorno and Max Horkheimer at the time, I also interpret Spengler as an overlooked stimulus to their Dialectic of Enlightenment (1947). As a conclusion, I ask whether it was exactly Adorno's daring effort to make Spengler's analysis of Caesarism serve progressive ends that today makes Adorno's critical theory an asset in understanding "Trumpism," the Caesarism of our own day.

\section{Caesarism: the decline of the Weimar Republic}

Richard Wolin stresses that as justified as it is to view the fascination with radical rightwing critics of reason as "an obligatory intellectual rite of passage" for many young leftwing intellectuals of interwar Germany, previous attempts to illuminate this connection have often lacked balance. "Proceeding by insinuation rather than sound argument," they have overemphasized the similarities and overlooked the differences. ${ }^{15}$ This danger should be avoided by all costs. Therefore, let us at the very outset bring forth all those countless aspects that Adorno objected to, indeed despised, in Spengler's Decline. This also serves as a brief recapitulation of the core themes of Spengler's book, for what Adorno rejected were just those arrogant historical and philosophical declarations that in 1918 had made Spengler's book part of the popular imagination almost overnight.

Adorno denounced as utter nonsense Spengler's "cultural morphology," that is, his notorious theory of the rise and fall of cultures. For Adorno, this theory was un-

\footnotetext{
${ }^{15}$ Wolin, "Walter Benjamin Today," 63-4.
} 
founded determinism that verged on astrological superstition at its worst. Equally untenable was Spengler's idea of collective cultural "souls," that is, unique dispositions to reality (f. e. Classical "Apollonian" or Western" Faustian") that supposedly dictated every single expression of a given culture. Contrary to Spengler's view of cultures as such self-enclosed monads, Adorno pointed out that "Faustian" technology had become a part of the way of life globally, even in the allegedly most resistant Russia and Japan. Again, although Adorno found much to complain in the Logos authors' attacks on Spengler, he shared their distaste of Decline's "sweeping administrative gesture," which "strips all phenomena down to the formula 'that's all happened before.'" No matter how problematic the positivist emphasis on facts was as a scientific methodology, it held its own when set against Decline's "tyranny of categories," a tyranny that was "closely related to the political tyranny about which Spengler is so enthusiastic." As for Spengler's political preferences, Adorno had nothing but contempt for his Proto-Fascist adoration of authority and sacrifice ${ }^{16}$ It is not an overstatement to say that Adorno found the entire idea of cultural morphology as a sign or a symptom of the Zeitgeist characterized by cynical power politics, fatalistic celebration of will-to-power, and anti-Enlightenment polemics.

What was, then, Adorno's problem with the critical approach to Spengler shown by the Logos authors in 1920 and Weimar academia in general? While they may have demolished Spengler's claims about this or that question of historical detail, in their unshaken trust in the triumph of reason and progress they had missed some unnerving tendencies in modern Western society. Spengler's academic adversaries had made a

\footnotetext{
${ }^{16}$ Adorno, "Spengler after the Decline," 66-71; Adorno, “Was Spengler Right?" 28. On Spengler's life and work, see Hughes, Oswald Spengler.
} 
grave error in refusing to ponder whether behind the undeniable flaws of Spengler's Decline there lay genuine insights, insights that they had paid scant attention to and which failed to resonate among laypeople as soon as the immediate postwar misery gave way to the "Golden Twenties." By these insights Adorno meant Spengler's observations, discussed under the label of "Caesarism" in the second, largely neglected, volume of Decline (1922), on the post-World War I Europe: bureaucratization of the party system, emergence of a new personality type susceptible to propaganda, and the rise of manipulative mass media. For Spengler, these phenomena marked the coming of the age of "Caesarism" - an age of urban metropolis, shallow materialism, and ruthless thrust for power: an inevitable late stage that every "culture" had to face as it reached the old age of "civilization." For Adorno, however, these observations were valuable not as validation of Spengler's cultural morphology, but as keys to more specific discontents of interwar Europe.

First, there was Spengler's view that democracy has been "well in the decline" since the war. Considering the collapse of four empires in 1918 and the establishment of numerous new republics from Baltic to Iberia, this view invites skepticism. Spengler highlighted, however, the profound transformation of the parliamentary system. Modern political parties, employing thousands of people, were more interested in guarding special interests of their members than in deliberating over the common good in an open dialogue. They had become bureaucratic machines far removed from the nineteenth-century ideal of a deliberative public sphere. This structural problem of the European party system, "Caesarism of the organizations," was reflected in the 1919 Weimar Constitution, which left itself vulnerable to undemocratic forces. Alluding to the infamous Article 48 , which allowed governing by emergence decrees without consent of the parliament, Spengler claimed that a major problem in the constitution is "visible already. A few quite 
small alterations and it confers unrestricted power upon individuals. ${ }^{17}$ Adorno found Spengler's observation on the bureaucratization of parties "radically confirmed in $\mathrm{Na}$ tional Socialism - parties became followings." While echoing cyclical political theorists of the past, Spengler was superior to thinkers such as Machiavelli "in having experienced the dialectic of history, though he never names it." Spengler never sympathized with democracy, yet he understood "the mechanisms which allow the party system to turn into dictatorship." 18

Facilitating the bureaucratization of parties and the subsequent rise of authoritarianism were psychological changes. Spengler noted that in the nineteenth century people were filling to fight for "the great truths of Democracy" and "rights without which life seemed not worth the living." Today, however, when these rights have become reality, "the grandchildren cannot be moved, even by punishment, to make use of them." Behind political apathy Spengler found atomization of urban metropolises. "The splendid masscities harbour lamentable poverty and degraded habits, and the attics and mansards, the cellars and back courts are breeding a new type of raw man."19 In Adorno's estimation, Spengler grasps the link "between atomization and the regressive type of man which revealed itself fully only with the onslaught of totalitarianism." Although unaware of the economic causes behind the emergence of this urban, "second nomad," Spengler was acutely aware of the role played by new mass media. ${ }^{20}$

\footnotetext{
${ }^{17}$ Spengler, The Decline Vol. II, 452, 457n2.

${ }^{18}$ Adorno, "Spengler after the Decline," 59.

${ }^{19}$ Spengler, The Decline Vol. II, 432, 102.

${ }^{20}$ Adorno, "Spengler after the Decline," 55-6.
} 
Indeed, Spengler lamented the replacement of "the book-world, with its profusion of standpoints that compelled thought to select and criticize" by newspapers. Today, "the people reads the one paper, 'its' paper, which forces its way through the front door by millions daily" and "spellbinds the intellect from morning to night." Depicting the "Caesars of the world-press" Spengler lamented that "no tamer has his animals more under his power. Unleash the people as reader-mass and it will storm through the streets and hurl itself upon the target indicated, terrifying and breaking windows." ${ }^{21}$ With a reference to the anti-Semitic Kristallnacht pogrom in Germany in 1938, Adorno suggested that "Spengler predicted Goebbels." What Spengler discerned in "the modest press magnates" of World War I era found "their mature form in the techniques of manipulated pogroms and 'spontaneous' popular demonstrations." ${ }^{22}$ Further illuminating the decay of critical thinking was Spengler's farsighted polemics against modern mass culture. Urban metropolitans had little understanding of "genuine play, joie de vivre, pleasure," whereas sports, gambling, and other "conscious and practiced fooling" functioned as muchneeded distractions from tense working life. ${ }^{23}$ Adorno credited Spengler for predicting the "static state of culture," which "compels the incessant and deadly repetition of what has already been accepted," while simultaneously "standardized art for the masses, with its petrified formulas, excludes history." ${ }^{24}$

I believe George Friedman is correct to point out parallels between Spengler's analysis of "Caesarism" and Adorno's criticisms of modern Western societies. In Dialectic

\footnotetext{
${ }^{21}$ Spengler, The Decline Vol. II, 461-2.

${ }^{22}$ Adorno, "Spengler after the Decline," 57.

${ }^{23}$ Spengler, The Decline Vol. II, 103.

${ }^{24}$ Adorno, "Spengler after the Decline," 56, 58.
} 
of Enlightenment (DE), Adorno and Horkheimer sought to capture the complex constellation of economic, political, and cultural forces that had molded the public sphere, the greatest achievement of bourgeois revolutions, into a commodified "culture industry" "enlightenment as mass deception." ${ }^{25}$ Again, in The Authoritarian Personality (1950) Adorno, together with his American colleagues, argued for the existence in United States of authoritarian potential that in less favorable societal conditions could be set on fire by America's homegrown Fascist demagogues. ${ }^{26}$ Finally, decay of democracy was not an alien concern for Adorno, who held "the growing concentration of the economy, the executive and the bureaucracy" as a major obstacle to individual self-determination. Because of these structural problems, even formally democratic institutions of post-1945 period struggled to keep alive an inner desire for freedom, threatened by political apathy and expanding allures of consumerism. ${ }^{27}$

Notwithstanding Spengler's chilling indifference to suffering, his lebensphilosophisch fatalism, and his economic dilettantism - that is, all the countless aspects that made Spengler's thought a sign of the unhealthy Zeitgeist poisoned by right-wing Zivilisationskritik-Adorno thought that Decline had touched on something essential of an age rushing to become one of "extremes," of Europe turning into a "dark continent." ${ }^{28}$ In Adorno's account, Spengler was not merely a symptom of his age, but offered genuine insights about it as well. By waiving Spengler off as a vulgar charlatan, his Weimar adversaries, from liberals to Marxists, had missed the forest for the trees. By no means does

\footnotetext{
${ }^{25}$ Horkheimer and Adorno, Dialectic of Enlightenment, 94-136.

${ }^{26}$ Adorno et al., The Authoritarian Personality.

${ }^{27}$ Adorno, History and Freedom, 5-7.

${ }^{28}$ See Hobsbawm, The Age of Extremes; Mazover, Dark Continent.
} 
this mean that Spengler would have understood the real roots of the discontents of the times, let alone properly theorized their interconnections. Yet I believe that Adorno saw his observations as containing kernels of truth. No matter how problematic, they gave a lot of food for thought. This dialectical logic at work in Adorno's ambiguous stance towards Spengler is well captured in the following passage:

Spengler is one of the theoreticians of extreme reaction whose critique of liberalism proved itself superior in many respects to the progressive one. It would be worthwhile to investigate the reasons for this. It is the differences in the relationship to ideology that are decisive. To the adherents of dialectical materialism liberal ideology seemed for the most part a false promise. Their spokesmen questioned not the ideas of humanity, freedom, and justice but rather the claim of bourgeois society to have realized those ideas. Ideologies were appearances for them, but the appearance of truth nevertheless. As a result, if not the existent itself at least its "objective tendencies" were endowed with a conciliatory gloss. Talk of the increase of antagonisms and the admission of a real possibility of a regression to barbarism were not taken seriously enough for anyone to recognize ideologies as something worse than apologetic disguises, as the objective absurdity that aids the society of liberal competition to turn into a system of direct oppression. $^{29}$

\footnotetext{
${ }^{29}$ Adorno, "Spengler after the Decline," 65.
} 
Spengler had paid attention to early marks of a path that would lead to this new "system of direct oppression." This was possible, Adorno reasoned, because he rejected the optimistic conception of history as steadfast progress, a conception cherished by those who thought history was on its way towards something like a "realm of freedom." Liberals of the Weimar Germany believed in the triumph of parliamentary system. Marxists thought that capitalism would give way to socialism out of a historical necessity. Neither camp was truly alert to the possibility that a new kind of barbarism, Fascism, was looming on the horizon. As much as Adorno cherished the enlightened ideals of liberals and Marxists, he applauded Spengler for offering insights into why the world was moving away from these ideals. "Spengler's harshness with his contemporaries," Adorno maintained, "might almost have constituted a shock which might have helped to save them." ${ }^{30}$

Adorno would have considered it a disgrace that there ever was a serious debate whether history consisted in Spengler's self-enclosed and plant-like cultures. Quoting approvingly James T. Shotwell's early criticism of Decline, he emphasized that historical civilizations "have been inherently lacking in equilibrium" not because of some cosmic forces but because "they have built upon the injustice of exploitation." There was, however, no reason to presume that "modern civilization must inevitably repeat this cataclysmic rhythm. ${ }^{\prime 31}$ In other words, there were far more plausible explanations than Spengler's fanciful cultural morphology both for the demise of classical Greco-Roman world and for the discontents of interwar Europe. At the same time, however, Adorno wished to give Spengler's suspicion of progress its due. Writing in Germany of the 1950s, Adorno wanted

\footnotetext{
${ }^{30}$ Adorno, “Was Spengler Right?” 29.

${ }^{31}$ Adorno, "Spengler after the Decline," 71-2; Shotwell, "Spengler," 228-9.
} 
to avoid the mistakes of the progressives of the Weimar era, whose well-meaning celebrations of reason, culture, and justice had not been enough. "Spengler could laugh in the face of such blissful confidence. Rather, it is the barbaric element in culture itself which must be recognized." ${ }^{32}$

Adorno did not think that the post-1945 Germany faced any imminent threat of repeating the fate of the Weimar Republic. There was no denying that many things had gotten better. But problems remained, most notably the concentration of societal power and Germans' inability to genuinely work through the past that had led to Hitler. As Adorno famously expressed his concerns, "the survival of National Socialism within democracy" was a more urgent threat than "survival of fascist tendencies against democracy" (that is, marginal neo-Nazi organizations). ${ }^{33}$ Adorno's appreciation of Spengler was, then, understandable after horrors of total war and especially after the Holocaust. This appreciation, however, was not a product of the postwar era. The original version of Adorno's Spengler essay dates from 1941-a fact often overlooked in previous commentaries-and it needs to be understood within the context Frankfurt School's reflections on "state capitalism" in New York.

\section{Caesarism and state capitalism: rethinking Spengler in New York}

In 1938, Adorno joined the Institute for Social Research in New York where it had relocated from Frankfurt in 1934. Between 1938 and 1941, he lectured at least twice on

\footnotetext{
32 Adorno, "Spengler after the Decline," 71.

${ }^{33}$ Adorno, "The Meaning of Working Through the Past," 90, 99; Adorno, "Was Spengler Right?" 26.
} 
Spengler at Columbia University. ${ }^{34}$ Based on these lectures, an essay titled "Spengler Today" appeared in the Institute's journal in 1941. Commenting on the draft of the essay, Horkheimer demanded that it "absolutely has to be in the next issue, it fits perfectly to the theme." 35 The theme was "state capitalism," introduced by Friedrich Pollock, the house economist of Horkheimer's circle. Pollock maintained that in the wake of the 1929 Wall Street crash capitalism had undergone a major transformation. Nazi Germany, Soviet Union, and the New Deal USA had surrendered economic competition to state administration, thereby eliminating the market as the dynamic regulator of social relationships. This transformation culminated a longer historical trend, in which nineteenth-century "liberal capitalism," competition of private entrepreneurs, gave way at the turn of the century to "monopoly capitalism" of large corporations, conglomerates, and joint-stock companies. This centralization of power reached its zenith in the fusion of economic and political power in the "state capitalism" of the 1930 s. $^{36}$

The somewhat ironic outcome of Pollock's thesis was that an economist surrendered economy as an independent realm to politics. In a well-known debate at the Institute, Horkheimer and Adorno sided with Pollock while others, such as Franz Neumann, the author of Behemoth: The Structure and Practice of National Socialism (1942), did not. A lot was at stake, especially concerning the German situation. "State capitalism" meant the awkward realization that contrary to what more orthodox Marxists believed, Nazi Germany was not threatened from within by any insurmountable economic antagonism.

\footnotetext{
${ }^{34}$ Adorno to Maria and Oscar Wiesengrund, March 28, 1944, in Briefe an die Eltern, 253-4; Adorno to Horkheimer, May 3, 1941, in Briefwechsel 1938-1944, 109.

${ }^{35}$ Horkheimer to Adorno, June 23, 1941, in Briefwechsel 1938-1944, 155.

${ }^{36}$ Pollock, "State Capitalism," 200-25.
} 
To be sure, economic inequalities and systemic problems had in no way been overcome. Yet the "authoritarian state" - the Nazi party, bureaucracy, military, and big industrycould deal with them in various ways from investments to open terror. And as great as the differences between European totalitarianisms and the democratic USA were, also in the latter the individual mattered less and less amidst the pressure of systemic forces. ${ }^{37}$

Adorno's Spengler essay was a contribution to this problematic. Adorno suggested that whereas Pollock had captured the economic dimension of the centralization of power, Spengler had observed, under the title of "Caesarism," psychological, cultural, and political dimensions of this same tendency in the early 1920s. Characteristic of the era of "Caesarism," Adorno emphasized, was its ahistorical character "in a most sinister sense." With a reference to Pollock's article-omitted from the 1950 version-Adorno continued that Spengler's "paradoxical prognosis is clearly paralleled by the tendency of present economy to eliminate the market and the dynamics of competition" and replace them with "static conditions" in which "the life of those who do the work is maintained planfully from above." ${ }^{38}$ On Adorno's account, Pollock and Spengler registered the perplexing fact that history had in fact vanished. Certainly, there was no shortage of world-historical events in the early twentieth-century. But the striking feature of this era was that individuals did not make history. They were increasingly not subjects of their fate, but objects of supra-individual forces. Contrary to enlightenment promises of autonomy, individuals were not in charge of societal development, but cogs in the machine. This development reached its zenith under the totalitarian regimes of the 1930s, but its seeds had been

\footnotetext{
37 Jay, The Dialectical Imagination, 143-66; Wiggershaus, The Frankfurt School, 280-291.

${ }^{38}$ Adorno, "Spengler Today," 310.
} 
sown under democratic conditions of the 1920s. Besides the replacement of private entrepreneurs by monopolies and state administration, this tendency manifested itself also in political, psychological, and cultural realms as demonstrated by Spengler. ${ }^{39}$

The similarities between Adorno and Spengler are, then, palpable. But what about Spengler's possible influence on Adorno? George Friedman is vague about this question. He writes about Spengler's "direct influence" and maintains that the Frankfurt School "incorporated Spengler's criticism into their own." Yet he qualifies his position by stating that Spengler's ideas only "find echoes" in their writings. ${ }^{40}$ If we follow Adorno's path of thinking up to his arrival in New York in 1938, it seems doubtful that Spengler would have left a notable imprint on his intellectual development. Indeed, the young Adorno's rare remarks on Spengler in the Weimar-era suggest that he saw in the latter's ideas mere mystification of economic injustices. ${ }^{41}$ Of course, the following scenario is possible. Adorno later conceded that while he had not expected Hitler's regime to last long-the average length of Weimar governments was eight months-already in the 1920s he had dark premonitions of things to come: "The outbreak of the Third Reich did, it is true, surprise my political judgment, but not my unconscious fear." ${ }^{42}$ We could speculate that

\footnotetext{
${ }^{39}$ It may be noteworthy that in the 1941 essay, unlike in the 1950 version, Adorno does not mention Robert Michels's Political Parties: A Sociological Study of the Oligarchical Tendencies of Modern Democracy (1911) or Werner Sombart's Why Is There No Socialism in America (1906) as likely influences on Spengler's idea of "Caesarism." This could mean that in 1941 Adorno still saw Spengler as a more original thinker than in 1950, when he suggested that doctrines like Michels's "iron law of oligarchy" had inspired Spengler. Adorno, "Spengler after the Decline," 55, 59; Adorno, "Was Spengler Right?" 26.

${ }^{40}$ Friedman, The Political Philosophy of the Frankfurt School, 80, 85.

${ }^{41}$ Adorno, Der Begriff des Unbewussten, 319-20.

${ }^{42}$ Adorno, Minima Moralia, 192.
} 
Spengler's Decline was one source behind Adorno's deeply-felt unease amidst the seemingly merry "Golden Twenties," and that Pollock's "state capitalism" thesis later offered a more compelling economic explanation for it. But this speculation is just that. It seems more plausible that Spengler only began to preoccupy Adorno's mind in New York in the late 1930s.

Adorno later described his Spengler essay as an outgrowth of debates in New York with other émigré intellectuals, among them the theologian Paul Tillich (Adorno's ex-supervisor and colleague in Frankfurt), and such American colleagues as the historian Reinhold Niebuhr. ${ }^{43}$ What all these discussants shared was a soft spot, despite their progressive political leanings, for Spenglerian pessimism. ${ }^{44}$ It was in these surroundings that Adorno engaged in a rethinking Spengler's worth. Rather than as an expression of Spengler's influence on Adorno, however, "Spengler Today" should be taken as an ex-post recognition of certain parallels between two otherwise very different thinkers. Nevertheless, at the same time I believe it would be equally incorrect to conclude that there is nothing more to be found in Adorno's essay that this ex-post recognition. For we still have not touched on the question of whether Adorno's reflections on Spengler in 1941 suggest that Spengler influenced, or stimulated, his subsequent thinking. This question is pertinent, for Adorno's New York years were the incubation time of Dialectic of Enlightenment that he and Horkheimer began to write in 1941 in California.

\footnotetext{
43 “Erinnerungen an Paul Tillich," 35. See also Adorno to Horkheimer, May 3, 1941, in Briefwechsel 1938$1944,109$.

${ }^{44}$ On Spengler's impact on Tillich and Niebuhr, see Clayton, The Concept of Correlation, 143; Stone, Professor Reinhold Niebuhr, 41.
} 
"Masterpiece" was how Horkheimer described Adorno's Spengler essay; despite the preciseness of its treatment of details, Adorno's treatment adhered to what was essential in Spengler. Moreover, Horkheimer emphasized that the essay highlighted themes especially important today and in need of further reflection, such as the idea of "ahistorical character of the present," a provocative and paradoxical idea in an era filled with events of world-historical magnitude (Hitler's invasion of Soviet Union had begun in the previous day). Bespeaking Horkheimer's enthusiasm was that whereas Adorno had judged Spengler as a dilettante in economic matters, in Horkheimer's opinion Spengler had real insights here too, particularly pertaining to the shift from liberal to monopoly capitalism. ${ }^{45}$ These words should not come as a surprise, for by 1941 Horkheimer, who also attended the New York debates mentioned above, had begun to feel more at home amid such sweeping civilizational ruminations.

The debate over state capitalism, as often noted, marked a pessimist turn in Horkheimer's thinking. Besides Pollock's thesis, affecting this turn were depressing political events, most notably the 1939 Molotov-Ribbentrop pact, and Horkheimer's increasing contacts with Adorno. Of course, for Horkheimer philosophical perspective on historical and economic phenomena had always been essential. Thus, if Pollock saw state capitalism culminating a decades-long economic trend, Horkheimer viewed it through the lens of "dialectic of bourgeois society" (John Abromeit's term), a sort of Hegelian-FreudianMarxist modification of Max Weber's idea of ascetic Protestant roots of modern capitalism. By 1941, however, Horkheimer's scope had expanded from centuries to millennia, as evidenced by his article "The End of Reason," in which his earlier careful differentiations

\footnotetext{
${ }^{45}$ Horkheimer to Adorno, June 23, 1941, in Briefwechsel 1938-1944, 153-4.
} 
between historical periods, thinkers of the same period, and present political systems had given way to a more ruthless critique of Western reason as such. This transformation was certainly not straightforward, and Horkheimer's life-long admiration of Schopenhauer's pessimism remains a challenge for his biographers. ${ }^{46}$

Anyhow, with regards to Spengler there is an apparent change in Horkheimer's stance. Earlier he had not minced words with Spengler's dilettantism and irrational reduction of human history to blind nature. ${ }^{47}$ But Horkheimer's praise of Adorno's Spengler essay shows that by 1941 he had changed his mind. This did not go unnoticed by Adorno. "I am especially happy," he replied, "that you really liked the Spengler [essay]. You cannot imagine what our agreement in these things means to me." ${ }^{48}$ Hence, considering that both Adorno and Horkheimer showed appreciation for Spengler in 1941, I believe it is not far-fetched if we next turn to weigh the possibility that Spengler stimulated DE, that the book was partly an immanent critique of his ideas. Adorno had criticized Spengler's progressive adversaries in the 1920s for taking the easy way out by playing culture against barbarism instead of recognizing "the barbaric element in culture" itself. Is not DE with its narrative of the entwinement of myth and reason an effort at just such a recognition?

When Adorno mentioned the future title of the book for the first time, he referred to it as "dialectic of enlightenment or dialectic of culture and barbarism." ${ }^{49}$

\footnotetext{
${ }^{46}$ Abromeit, Max Horkheimer, 394-424; Horkheimer, "The End of Reason," 366-88.

${ }^{47}$ Horkheimer, "Zur Emanzipation der Philosophie," 295.

${ }^{48}$ Adorno to Horkheimer, July 2, 1941, in Briefwechsel 1938-1944, 159.

${ }^{49}$ Adorno to Horkheimer, November 10, 1941, in Briefwechsel 1938-1944, 286.
} 


\section{Spengler as a key to Dialectic of Enlightenment?}

In 1944, Adorno and Horkheimer circulated a small amount of mimeographic copies of Philosophical Fragments, a work that was officially published in 1947 as Dialectic of Enlightenment. Uniting this darkest of books was a desperate effort to comprehend why after two and a half millennia of Western rationalism "the wholly enlightened earth is radiant with triumphant calamity": with Nazism, Stalinism, and Western culture industry. ${ }^{50}$ The emergence of human subjectivity from nature, Adorno and Horkheimer argued, had come with a high price of domination of outer and inner nature. Since pre-Socratic times, self-preservation had been bought with self-renunciation, and periods of genuine freedom seemed like aberrations from the norm. To make at all convincing my tentative reading of Spengler as a key to this narrative, it is imperative to show why Spengler, who is not mentioned in $\mathrm{DE}$, can hold his own against such oft-cited influences as Max Weber, Sigmund Freud, and Walter Benjamin. Encouraging this attempt are Adorno's remarks in and on his Spengler essay (the epigraph) and Horkheimer's endorsement of it in $1941 .^{51}$

$D E$ is often seen as inspired by Weber's portrait of "the apparently ever-moving but, in reality, static iron cage of modernity," in which calculative rationality of capitalism suffocates different value spheres of politics, law, science, and rrt. $^{52}$ The resemblance between Weber's diagnosis and the idea of state capitalism, in which "the enthronement of the means as the end" has come to approximate "overt madness," is striking. ${ }^{53}$ Although

\footnotetext{
${ }^{50}$ Horkheimer and Adorno, Dialectic of Enlightenment, 1.

${ }^{51}$ Adorno to Horkheimer, May 3, 1941, in Briefwechsel 1938-1944, 109.

52 Bernstein, “Negative Dialectics as Fate," 21.

${ }^{53}$ Horkheimer and Adorno, Dialectic of Enlightenment, 43.
} 
DE does not mention Weber, Dana Villa is the latest to argue that "it is impossible to imagine the book without him." Whether this omission was due to "authorial pride and the anxiety of influence," or suspicion of possibly reactionary political ramifications of Weber's thought, it enabled Adorno and Horkheimer to veil the extent to which Weber offered "the foundation and basic conceptual structure of much, if not all, of their work." Indeed, besides the phenomenon to be explained, the modern "iron cage," Weber has also been seen as an inspiration for DE's explanative efforts. In Jürgen Habermas's estimation, both Weber and DE held the societal crisis of the twentieth-century Europe as an almost inevitable result of Western reason as such. Weber saw behind the iron cage the "disenchantment of the world," a development that in the post-Reformation era freed science, morality, and art from the straitjacket of religious and metaphysical dogmas, but also let loose calculative economic rationality. The opening page of DE contains an allusion to Weber's theory: "Enlightenment's program was the disenchantment of the world." ${ }^{55}$ Echoing Weber, DE saw modern differentiated reason as unreason; science served bureaucratization, secular morality disclosed itself as immorality (Sade), and commodified culture industry swallowed critical impulses of art. Read through the lens of "reification" of Weber's Marxist student Georg Lukács, Weber's theory of rationalization became DE's theory of instrumental reason. ${ }^{56}$

Apart from the above allusion, however, DE does not discuss Weber, and there is no evidence of Adorno's and Horkheimer's sustained engagement with his thought. To be sure, this need not mean that Weber would not have influenced them. But lack of such

\footnotetext{
${ }^{54}$ Villa, "Weber and The Frankfurt School," 266-68.

${ }^{55}$ Horkheimer and Adorno, Dialectic of Enlightenment, 1; Weber, “Science as a Vocation," 139, 155.

${ }^{56}$ Habermas, The Theory of Communicative Action. Vol. 1, 366-99.
} 
explicit concessions invites consideration of other candidates, such as Spengler. Weber's theory of rationalization, Adorno noted in 1964, was preoccupied with the same phenomenon as Spengler's "perspectives on solidification in Caesarist late times." Both Weber and Spengler offered trenchant observations on the interwar Europe. Adorno applauded Weber for having predicted the victory of bureaucracy over democracy in Soviet Russia, ${ }^{57}$ while elsewhere he praised Spengler's observations on ominous tendencies at work behind the sunny republican facade of Weimar Germany.

Moreover, commenting enthusiastically on Adorno's meditations on "Caesarism" in his 1941 Spengler essay, Horkheimer proposed that "one should consider in detail whether not history has actually always consisted in being none-except for few moments. Perhaps the concept of history requires disintegrating criticism. ${ }^{158}$ Horkheimer's comment indicates that Spengler, besides providing a provoking diagnosis of the present (Caesarism), may also have offered important theoretical stimulation to DE's idea of instrumental reason, and indeed more so than Weber's rationalization thesis. By this I do not mean Spengler's "cultural morphology" but his anthropological conception of the origins of human species and domination of nature, a conception that already underlay Decline but was only explicitly articulated in the 1931 Man and Technics (Der Mensch und die Technik). Whereas Weber traced occidental rationalization to Calvinist reformation, Spengler saw the roots of the domination of nature in the origins of civilization. He thus came closer than Weber to DE's effort, in Habermas's words, to trace instrumental reason "back behind the capitalist beginnings of the modern age into the very beginnings of

\footnotetext{
${ }^{57}$ Adorno, Nachgelassene Schriften, 18-19.

${ }^{58}$ Horkheimer to Adorno, June 23, 1941, in Briefwechsel 1938-1944, 154.
} 
hominization." ${ }^{59}$ Indeed, in his Spengler essay Adorno claimed that Decline's biggest flaw was its mistaken conception of the relationship between humans and nature. Spengler's seemingly concrete, but in truth, idealist conception had no room for real material needs, for humanity's "desire to survive." Culture was not, Adorno argued, "the life of self-developing collective souls" but contained "an element of resistance to blind necessity: the will for self-determination through Reason." He insisted that "freedom develops only through the natural world's resistance to man. Freedom postulates the existence of something non-identical." 60

This would become the central argument of DE; from the struggle between humanity and nature resulted both the domination of and emancipation from natural forces. Manfred Gangl notes this crucial difference between Decline and DE without, however, suggesting that DE resulted from an actual contestation with Spengler. ${ }^{61}$ Indeed, apart from George Friedman's brief take on the topic, Spengler's possible presence in DE has received scant attention, as previous attempts to identify the book's anonymous lebensphilosophisch interlocutor have, following Axel Honneth, turned to Ludwig Klages and his vitalist attack on modern "logocentrism" in The Spirit as Adversary of the Soul (Der Geist als Widersacher der Seele, 1929-32). ${ }^{62}$ Even David Roberts, who underscores the domination of nature as the common theme Adorno shared with Spengler, limits his exploration to Adorno's Philosophy of New Music (Philosophie der neuen Musik)

\footnotetext{
${ }^{59}$ Habermas, The Theory of Communicative Action, Vol. 1, 366.

${ }^{60}$ Adorno, "Spengler Today," 322.

${ }^{61}$ Gangl, “The Controversy over Friedrich Pollock's State Capitalism," 30-1.

${ }^{62}$ Friedman, The Political Philosophy of the Frankfurt School, 82-4; Honneth, "Anthropologische Berührungspunkte." See also Wellmer, The Persistence of Modernity, 3-4; Stauth, "Critical Theory and Pre-Fascist Social Thought."
} 
and the traces of Spengler's morphology of Faustian music in Adorno's theory of musical rationalization. ${ }^{63}$ Yet, as the epigraphs of the present article indicate, besides Klages's doctrines we should also see Spengler's "anthropological dialectics of nature" - as Adorno dubbed Spengler's conception in his critical 1932 review of Man and Technics ${ }^{64}$-as the source that provoked Adorno and Horkheimer to meditate on instrumental reason in their magnum opus. Further speaking for this conclusion is yet another intriguing comment by Horkheimer on Adorno's Spengler essay. Horkheimer suggested that Adorno's critique of Spengler's conception could function as a springboard for DE: "We can reopen [the theme of] the dialectic of nature from here. ${ }^{\prime 65}$ Let us examine this connection in more detail.

In Man and Technics, Spengler cast the human being as a beast of prey, "a foe to everyone, killing, hating, resolute to conquer or die." With his hand and thought this "inventive carnivore" had impacted the entire globe to such a degree that it seemed appropriate "to call his brief history 'world-history.'" Yet this history, in which nature formed merely "a background, an object, and a means," was not that of freedom and justice. Instead, a path led "from the primeval warring of extinct beasts to the processes of modern inventors and engineers" and "from the trick, oldest of all weapons," to modern technology. But this was a Faustian tragedy in Goethe's sense, for domination turned against human beings themselves. "The thinking, the intellect, the reason" sets "itself up against soul and life." To his mighty calculative capacity, the human being "sacrifices an important element of his own life," for it "requires a firmer and firmer hold on the life of the

\footnotetext{
${ }^{63}$ Roberts, Art and Enlightenment, 73, 81; Adorno, Philosophy of New Music.

${ }^{64}$ Adorno, Review of Der Mensch und die Technik, 149-51.

${ }^{65}$ Horkheimer to Adorno, June 23, 1941, in Briefwechsel 1938-1944, 154.
} 
soul." This tragedy was universal, but it reached its climax in modern European "machine culture," which was rapidly moving towards its end. Yet Spengler saw something dignifying in all this. It resided in resolutely following the dictates of one's own culture, its soul. "The honourable end is the one thing that can not be taken from man." ${ }^{66}$

Adorno and Horkheimer often come close to Spengler's view that there is only one logic in history: "The awakening of the subject is bought with the recognition of power as the principle of all relationships." This history begins with myths, first attempts at rational mastery of nature, which conceive the world in terms of "cyclical motion, fate, [and] domination." Self-preservation can only be won by sacrificial adjustment to the rules of the game without a hope for changing them. Enlightenment continues this mythic logic by other means. "Repetition, in the guise of regularity, imprisons human beings in the cycle now objectified in the laws of nature." Francis Bacon's celebration of the "'happy match' between human understanding and the nature of things" conceives knowledge as power and utility. Modern positivism has as little room for myths and religion as it has for unsystematic and unmathematical ideas like freedom or human rights. ${ }^{67}$ DE diverged decisively, however, from Spengler by stressing that cognitive domination was founded on social domination: "the moment the individual emerges from nature, property and women fall under his dominion." Millennia of enlightenment have failed to undo social oppression. Rather than defending difference, from "the classroom to the trade union" it preaches conformity. Liquidation of the market, Nazi anti-Semitism, and culture industry seal the deal. But Adorno and Horkheimer see a way out. The impulse to dominate does not originate in some "carnivore ethics" or mysterious dictates of

\footnotetext{
${ }^{66}$ Spengler, Man and Technics, 11-12, 22, 25-6, 40-4, 57-9, 69, 90, 103-4.

${ }^{67}$ Horkheimer and Adorno, Dialectic of Enlightenment, 2-10, 20-22.
} 
the Faustian "soul," but in real fear in the face of overpowering nature. Most importantly, civilization has advanced "not only mastery but also the prospect of its alleviation." Everything depends on thinking becoming self-reflective. Besides abstract formalism that distances humans from nature and each other, thinking also "enables the distance that perpetuates injustice to be measured. Through this remembrance of nature within the subject, a remembrance which contains the unrecognized truth of all culture, enlightenment is opposed in principle to power." This happens in Hegel's "determinate negation," which understands by truth not increasing distance from objects but disclosure of their "social, historical, and human meaning."

From DE's perspective, Spengler's eyes, although little selective, did not lie in viewing previous history as unrestrained domination. Yet by seeing no alternative, Spengler misunderstood second nature as first, appearance as essence. In Decline, Spengler constructed his cyclical theory of history upon an unquestionable belief in all-encompassing will-to-power. For Adorno and Horkheimer, this was a view of history caught in myth. Again, in Man and Technics, subtitled "a contribution to a philosophy of life," Spengler ironically succumbed to overt intellectualism by ignoring material needs and bodily affectivity as the real motor of history. By celebrating resignation as something heroic, Spengler took the domination of inner nature to its extreme. It was Adorno's emphasis on just this dubious connection in Spengler's thought between absolute subjectivity ("cultural

\footnotetext{
${ }^{68}$ Horkheimer and Adorno, Dialectic of Enlightenment, 17-22, 32. Although Friedman rightly sees Spengler as an inspiration behind $D E$, he oversimplifies things by maintaining that Adorno and Horkheimer sympathized with "Spengler's emphasis on the cultural event as the ground of historical being." I would contend, in contrast, that although the Marxist critique of political economy is absent in $\mathrm{DE}$, the book nevertheless builds on a materialist foundation by stressing affectivity and material needs as well as social domination as decisive in history. Friedman, The Political Philosophy of the Frankfurt School, 82-4.
} 
souls"), unaffected by natural factors, and absolute bondage (resignation to the dictates of these souls) that Horkheimer had praised in his comments on Adorno's essay and proposed as a point of departure for their own meditations on history.

This analysis suggests, then, that Spengler stimulated Adorno and Horkheimer's critique of domination of nature. Both saw in Adorno's Spengler essay important insights that could function as a springboard for DE. Certainly, other works were considered too: Adorno's Philosophy of New Music (the first part of which dates from 1940-41) and Horkheimer's "The End of Reason." Nor should we forget the 1942 debate in the Institute over Friedrich Nietzsche as another signpost in the early Frankfurt School's (especially Horkheimer's) path from Marxist ideology critique to a more sweeping critique of entire Western civilization. ${ }^{69}$ The core theme in these works and in the Nietzsche debate, however, was the same as in Adorno's Spengler essay: domination of outer and inner nature as the definitive feature of Western history.

What about Freud? The Frankfurt School would be unthinkable without Freud's libido theory and his emphasis on human beings' natural condition as a key to understanding their history. Freud offered a psychoanalytical account of the emergence of human subjectivity from nature and bemoaned how this civilizing process had hardened humans' affective capacities to such a degree that they struggled to enjoy the fruits of this process. ${ }^{70}$ As to modern Europe, Freud questioned "the liberalistic illusion that the pro-

\footnotetext{
${ }^{69}$ Horkheimer to Adorno, August 28, 1941, in Briefwechsel 1938-1944, 212-18; Abromeit, Max Horkheimer, 394-5. On the Nietzsche debate, see "Special Section on Frankfurt School and Nietzsche," 127-47.

${ }^{70}$ Freud, Civilization and its Discontents.
} 
gress of civilization would automatically bring about an increase of tolerance and a lessening of violence against out-groups." ${ }^{71}$ The Authoritarian Personality (1950) relied on Freud to explain what it saw as a new authoritarian character type: "enlightened and superstitious, proud to be an individualist and in constant fear of not being like all the others, jealous of his independence and inclined to submit blindly to power and authority."72 One commentator even describes the book as "a continuation of the Dialectic of Enlightenment by other means." ${ }^{73}$

But as undeniable as Freud's presence in DE is, Adorno and Horkheimer never identified with him entirely. For them, racist prejudice, or psychological phenomena in general, was not independent from larger societal forces. Indeed, contrary to the official stand of The Authoritarian Personality they maintained that most recent history, with its increasing concentration of power, had made psychoanalysis obsolete. The autonomous individual of the liberal-capitalist period, the model for Freud's thought, no longer existed. For Adorno and Horkheimer, fascism and culture industry had undermined the very foundations of the individual and were, in the words of their colleague Leo Löwenthal, “psychoanalysis in reverse." 74

Spengler's analysis of "Caesarism," in contrast, paid attention to political and cultural factors facilitating the decline of the individual. Although the exact dialectic interconnecting these factors escaped Spengler, their outcome, the atomized urban citydweller, was at the heart of his analysis. Adorno always insisted that ego-weakness was

\footnotetext{
${ }^{71}$ Adorno, "Freudian Theory and the Pattern of Fascist Propaganda," 129.

${ }^{72}$ Adorno et al., The Authoritarian Personality, Ixxi.

${ }^{73}$ Müller-Doohm, Adorno, 292.

${ }^{74}$ Gordon, "The Authoritarian Personality Revisited," 59-67. For Adorno's deviation from the official line of The Authoritarian Personality, see Adorno, "Remarks on The Authoritarian Personality" (1948).
} 
not limited to people living under totalitarian regimes. In 1950, the year The Authoritarian Personality was published, he wrote to Thomas Mann about Spengler's "caveman" as a fitting characterization not only of the Germans of the Nazi era, but also those of the postwar period. ${ }^{75}$ And in 1964 , in discussing Spengler and Freud, Adorno cited David Riesman's idea of the other-directed character as an apt diagnosis of the widespread egoweakness in the United States. ${ }^{76}$ To be sure, Adorno applauded Freud's Civilization and its Discontents (Das Unbehagen in der Kultur) for the attention it gave to the qualitatively new pressures of modern industrial society, simultaneously criticizing Spengler's ahistorical cultural morphology. ${ }^{77}$ Yet as we have seen, elsewhere Adorno praised Spengler's historically sensitive analysis of "Caesarism" for similar insights against Spengler's own selfunderstanding as a morphologist of historical invariants.

Finally, we have Benjamin. "There is no document of culture which is not at the same time a document of barbarism.."78 This sentence from Benjamin's so-called theses on the philosophy of history, written shortly before his tragic suicide in 1940 and published posthumously as “On the Concept of History" (Über den Begriff der Geschichte), reads like a crystallization of the message of DE. Indeed, upon receiving a copy of Benjamin's theses from Hannah Arendt in June 1941, Adorno reported in an oft-cited letter to Horkheimer that “none of Benjamin's works shows him closer to our own intentions. More than anything it is about the idea of history as a permanent catastrophe, the critique of progress as domination of nature, and the stance towards culture." On less well-

\footnotetext{
${ }^{75}$ Adorno to Mann, June 3, 1950, in Adorno - Mann. Briefwechsel 1943-1955, 61.

${ }^{76}$ Adorno, History and Freedom, 6-7; Riesman, The Lonely Crowd, 19-24.

77 Adorno, "Was Spengler Right?" 28.

${ }^{78}$ Benjamin, "On the Concept of History," 392.
} 
known lines of the letter, however, Adorno continued: "Here there is a coincidence that has moved me a lot. The sentence in thesis VII on culture und barbarism stands verbatim in the last paragraph of Spengler [essay]." ${ }^{\prime 79}$ In his Spengler essay, Adorno had polemicized against the naivety of Weimar intelligentsia by demanding awareness "of the element of barbarism inherent in culture itself." Written in April 1941, Adorno had composed his essay independently of Benjamin's theses: "We both knew nothing about each other's formulations." ${ }^{\prime 80}$

Nothing would be more foolish than to belittle Benjamin's weighty, and well-recorded, influence on Adorno and, by extension, to DE. Adorno's habilitation thesis, Kierkegaard (1933), and his lecture "The Idea of Natural-History" (1932) - which both offered a proto version of DE's idea of entwinement of myth and reason-built on Benjamin's 1928 Origin of the German Trauerspiel (Ursprung des deutschen Trauerspiels). Again, over the 1930s Adorno, despite his differences with Benjamin, waited enthusiastically for his friend to complete his grandiose lifework on the Paris arcades ("Passagenwerk"). ${ }^{81}$ And by 1941 Horkheimer, who earlier had disliked the geschichtsphilosophisch, quasi-theological bent of Benjamin's cultural criticism, had changed his mind. In the same letter that endorsed Adorno's Spengler essay, Horkheimer proposed that they adopt as “theoretical axioms" some of Benjamin's ideas. The most notable of these was Benjamin's claim that official historiography, by sympathizing with the victor, adores "cultural treasures" which

\footnotetext{
${ }^{79}$ Adorno to Horkheimer, June 12, 1941, in Briefwechsel 1938-1944, 144-5.

${ }^{80}$ Adorno to Horkheimer, June 12, 1941, in Briefwechsel 1938-1944, 145. The original draft, titled "Spengler und die gegenwärtige Situation," is dated April 18, 1941, Theodor W. Adorno Archive, Ts. 23399-23419. Adorno sent his essay to Horkheimer in late May; Adorno to Horkheimer, May 31, 1941, in Briefwechsel 1938-1944, 126.

${ }^{81}$ Buck-Morss, Adorno, Benjamin, and the Frankfurt Institute, 59, 168-75; Hullot-Kentor, "Critique of the Organic," xi, xv; Wolin, Walter Benjamin, 265-72.
} 
"owe their existence not only to the efforts of the great geniuses who created them, but also to the anonymous toil of others who lived in the same period." ${ }^{82}$

To conclude, it would be mistaken not to consider Spengler as a stimulation to DE's view that Western history, driven by science and technology, was not by chance anything but linear and unambiguous triumph of freedom. As Adorno insisted, Spengler "more strikingly than almost anyone else" has shown how "the raw nature of culture" time and again "drives it toward decay and how, as a form and order, culture is affiliated with that blind domination which, through permanent crises, is always prone to annihilate itself and its victims." ${ }^{83}$ Spengler's insight into "the dual character of enlightenment," in addition to those of Weber, Freud, and Benjamin, opened Adorno's eyes to the Janusfaced character of Western civilization. He credited Spengler for the ability to direct "attention towards the 'system' in the individual, even where it assumes a semblance of freedom which conceals the universal dependency." At the same time Spengler was utterly incapable of conceiving a qualitatively different future beyond the Hobbesian bellum omnium contra omnes that he, echoing the fatalistic Zeitgeist of interwar Germany, adored with morbid fascination. DE, as an effort at genuinely historical thinking, should be read as an attempt to divorce Spengler's Zivilisationskritik from its radical-conservative universe and to put it into service of "impulses which go beyond all previous history as the history of domination." ${ }^{84}$

\footnotetext{
${ }^{82}$ Horkheimer to Adorno, June 23, 1941, in Briefwechsel 1938-1944, 155; Benjamin, “On the Concept of History," 391-2.

${ }^{83}$ Adorno, "Spengler Today," 324.

${ }^{84}$ Adorno, "Spengler after the Decline," 61-62.
} 


\section{Trumpism: Adorno and the neoliberal Caesarism}

"The important question," Adorno emphasized, "is not how and why various historical epochs blindly displace each other, and which societies survive or decline," but "whether mankind will learn to determine itself. ${ }^{85}$ Until then, cheap dismissals of Spengler were premature. In the 1950s, Adorno found this question anything but untimely, no matter how much things had improved after 1945 . What about our twenty-first century West? The social-democratic welfare state was a promising step to the right direction, yet the neoliberal havoc since the late 1970s has created a world in which, especially in the aftermath of the 2008 economic crisis, this question appears urgent. Moreover, recent interest in Adorno's thought in the wake of Donald Trump's racist and misogynist presidential campaign in 2016 begs the question whether it was precisely Adorno's effort to make Spengler's analysis of "Caesarism" serve progressive ends that today makes his critical theory-instead of obsolete gloominess-an asset in analyzing authoritarian populism. Not long ago Adorno's thought was deemed outdated pessimism out-of-touch with the twenty-first century. But now he seems to have returned to shake the Frankfurt School tradition, guided for decades by the efforts of his most famous student, Jürgen Habermas, to update critical theory, shaped in the dark interwar era, to the more hopeful postwar world. Notwithstanding Habermas's laudable achievements in filling the "liberaldemocratic deficit" of the early Frankfurt School, defending enlightenment against postmodernism and EU-technocrats, and acting as Germany's public conscience over the past 70 years, critics claim that in his hands the Frankfurt School tradition has come to resem-

\footnotetext{
${ }^{85}$ Adorno, "Was Spengler Right?” 29.
} 
ble the Anglo-Saxon liberal tradition of John Rawls and others. Critics complain that Habermas is too focused on normative questions and too detached from deep historical analyses to explain why the world is moving towards inequality, racism, and ethno-populism instead of universal justice. In this situation, many commentators have argued for Adorno's relevance in explaining these troubling phenomena.

The Authoritarian Personality has been particularly appealing. Richard Wolin calls attention to authoritarians' hostility to all racial minorities (f. e. Jews and Muslims) and distrust of liberal-democratic principles. Persuaded by racist images of populist rhetoric, they replace "rational thought and policy goals with libidinal cathexis" with demagogic leaders like Trump. Although always controversial, The Authoritarian Personality has found corroboration in more recent American studies on Trumpism. ${ }^{86}$ Again, Samir Gandesha suggests that while ours is no longer the Ford-Keynesian economy of Adorno's days, his insights may be even more relevant today at the time of the "neoliberal personality." Neoliberal marketization of social relations promised to create a world in which individuals "can exercise their capacity to articulate their own interests autonomously and rationally within the context of a genuine plurality of other such interests." But by undermining the welfare state it has instead increased "a sense of social insecurity," created "surplus of aggression, humiliation and guilt," and strengthened "atavistic allegiances, xenophobic nationalism, racism and sexism. ${ }^{\prime 87}$ Even commentators less convinced by social-psychological explanations seek to build on Adorno's legacy. For Peter E. Gordon, right-wing populism is less about the fury of allegedly authoritarian, uneducated workers

\footnotetext{
${ }^{86}$ Wolin, "Our 'Prophet of Deceit'”; MacWilliams, The Rise of Trump.

${ }^{87}$ Gandesha, "'Identifying with the aggressor,'” 148-51.
} 
manipulated by the Fox News, than about long-term negative impact of the "culture industry" on critical thinking throughout the political spectrum. In similar vein, Max Pensky joins Adorno and Alexis de Tocqueville to trace the current authoritarian backlash to the depoliticizing potentials inherent in liberal democracy itself. ${ }^{88}$

Remarkably, the problems highlighted by these scholars-psychological effectiveness of populist propaganda, uncritical mass media, and decay of parliamentary virtuesare very much the same that Adorno called attention to in Spengler's portrait of "Caesarism." For Adorno, Spengler's merit was his focus on the question, not posed by the progressives of the 1920s, of why the world was moving away rather than towards freedom and justice. From the perspective of the resurgence of authoritarianism today, it seems that Adorno's effort to repurpose Spengler's "Caesarism" for left-wing ends gave him an edge over other progressive, but too optimistic, social theorists, such as Habermas, as well as those countless commentators who in the 1990s bought into Francis Fukuyama's notion of the "end of history." Nevertheless, we should carefully weigh the pros and cons of Adorno's effort to critically appropriate Spengler.

I would contend that Adorno both succeeded and failed in repurposing Spengler. The fruitfulness of Adorno's thought lies in his sober suspicion of historical progress and sensitivity to the fragile nature of democracy. The important thing is not to repeat the mistakes of Weimar champions of reason and enlightenment; today this would mean, for example, rejecting the uncritical belief in a necessary coexistence of capitalism and liberal democracy. I see this sober caution as a fruit of Adorno's engagement with dark thinkers

\footnotetext{
${ }^{88}$ Gordon, "The Authoritarian Personality Revisited," 67-79; Pensky, "Radical Critique and Late Epistemology," 85-124.
} 
such as Spengler. Yet, this engagement had as its downside Adorno's occasionally disproportionate pessimism. This is most visible in DE, which, even when acknowledged was written in the darkest possible hour, resulted in an almost total equation of Western reason with instrumental calculation. Even if it is true that DE's rare optimistic moments came more from Adorno's, rather than Horkheimer's, hand, only in comparison to thinkers like Spengler do these moments appear optimistic. ${ }^{89}$ From other perspectives, heartened by such recent examples as the Occupy Movement, Black Lives Matter, MeToo campaign, and young people's climate marches, DE succumbs to similar undifferentiated conception of bondage that Adorno criticized in Spengler. Adorno's thought is an asset in grasping the causes and appeal of authoritarianism today. Yet the Frankfurt School tradition contains even better sources to make sense of our neoliberal and authoritarian era. Rather than Adorno's pessimist or Habermas's optimistic positions, which both suffer from a lack of historical specificity, we should update Horkheimer's original, historically concrete idea of critical theory as a multidisciplinary analysis of capitalism, a position Horkheimer abandoned at the turn of 1940s largely due to Adorno's-and, as I have tried to show, Spengler's-influence. ${ }^{90}$

\section{References}

Abromeit, John. Max Horkheimer and The Foundations of the Frankfurt School. Cambridge: Cambridge University Press, 2011.

\footnotetext{
${ }^{89}$ On these rare glimpses of hope in DE and on the question of authorship, see Rabinbach, In the Shadow of Catastrophe, 169-71.

${ }^{90}$ What this update might look like today, see Abromeit, Max Horkheimer, 1-18 as well as Fraser and Jaeggi, Capitalism: A Conversation in Critical Theory.
} 
Adorno, Theodor W. Der Begriff des Unbewussten in der transzendentalen Seelenlehre. In Gesammelte Schriften Bd. 1, Philosophische Frühschriften, edited by Rolf Tiedemann, 79-322. Frankfurt am Main: Suhrkamp, 1973.

Adorno, Theodor W. Briefe und Briefwechsel-Bd. 3: Theodor W. Adorno/Thomas Mann. Briefwechsel 1943-1955, edited by Christoph Gödde und Thomas Sprecher. Frankfurt am Main: Suhrkamp 2002.

Adorno, Theodor W. Briefe und Briefwechsel-Bd. 4: Theodor W. Adorno/Max Horkheimer. Briefwechsel 1927-1969, Bd. II: 1938-1944, edited by Christoph Gödde und Henri Lonitz. Frankfurt am Main: Suhrkamp, 2003.

Adorno, Theodor W. Briefe und Briefwechsel-Bd. 5: Briefe an die Eltern 1939-1951, edited by Christoph Gödde and Henri Lonitz. Frankfurt am Main: Suhrkamp, 2003.

Adorno, Theodor W. "Freudian Theory and the Pattern of Fascist Propaganda." In The Essential Frankfurt School Reader, edited by Andrew Arato and Eike Gebhardt, 11837. New York: Continuum, 1988.

Adorno, Theodor W. History and Freedom: Lectures 1964-1965, edited by Rolf Tiedemann, translated by Rodney Livingstone. Cambridge: Polity Press, 2008.

Adorno, Theodor W. "The Meaning of Working Through the Past," translated by Henry W. Pickford. In Critical Models: Interventions and Catchwords, 89-103. New York: Columbia University Press, 2005.

Adorno, Theodor W. Minima Moralia: Reflections from Damaged Life, translated by E. F. N. Jephcott. London: Verso, 2000.

Adorno, Theodor W. Nachgelassene Schriften. Abteilung IV: Vorlesungen-Bd. 12: Philosophische Elemente einer Theorie der Gesellschaft, edited by Tobias ten Brink and Marc Phillip Nogueira. Frankfurt am Main: Suhrkamp, 2008.

Adorno, Theodor W. Philosophy of New Music. Translated and edited by Robert HullotKentor. Minneapolis: University of Minnesota Press, 2006.

Adorno, Theodor W. "Remarks on The Authoritarian Personality." In Theodor W. Adorno, Else Frenkel-Brunswik, Daniel J. Levinson and R. Nevitt Sanford. The Authoritarian Personality. London: Verso, 2019, xli-lxvi.

Adorno, Theodor W. Review of Der Mensch und die Technik: Beitrag zu einer Philosophie des Lebens, by Oswald Spengler. Zeitschrift für Sozialforschung 1, no. 1/2 (1932): 149-51. 
Adorno, Theodor W. "Spengler after the Decline." In Prisms, translated by Samuel and Shierry Weber, 51-72. Cambridge, MA: The MIT Press, 1981.

Adorno, Theodor W. "Spengler nach dem Untergang. Zu Oswald Spenglers 70. Geburtstag". Monat 2, no. 20 (1950): 115-28.

Adorno, Theodor W. "Spengler Today." Studies in Philosophy and Social Science 9, no. 2 (1941): 305-25.

Adorno, Theodor W. “Was Spengler Right?” Encounter 26, no. 1 (1966): 25-29.

Adorno, Theodor W. "Wird Spengler recht behalten?" Frankfurter Hefte 10, no. 12 (1955): 841-46.

Adorno, Theodor W., Else Frenkel-Brunswik, Daniel J. Levinson and R. Nevitt Sanford. The Authoritarian Personality. London: Verso, 2019.

Benjamin, Walter. "On the Concept of History" translated by Harry Zohn. In Selected Writings, Vol. 4, 1938-1940, edited by Howard Eiland and Michael W. Jennings, 389400. Cambridge, MA: Harvard University Press, 2003.

Bernstein, Jay M. "Negative Dialectics as Fate: Adorno and Hegel." In The Cambridge Companion to Adorno, edited by Tom Huhn, 19-50. Cambridge: Cambridge University Press, 2004.

Buck-Morss, Susan. The Origin of Negative Dialectics: Theodor W. Adorno, Walter Benjamin, and the Frankfurt Institute. New York: The Free Press, 1979.

Claussen, Detlev. Theodor W. Adorno: One Last Genius, translated by Rodney Livingstone. Cambridge, MA: Harvard University Press, 2008.

Clayton, John P. The Concept of Correlation: Paul Tillich and the Possibility of a Mediating Theology. Berlin and New York: De Gruyter, 1980.

Fraser, Nancy, and Rahel Jaeggi. Capitalism: A Conversation in Critical Theory, edited by Brian Milstein. Cambridge: Polity Press, 2018.

Freud, Sigmund. Civilization and its Discontents, translated by David McLintock. London: Penguin Books, 2002.

Friedman, George. The Political Philosophy of the Frankfurt School. Ithaca, NY: Cornell University Press, 1981.

Gandesha, Samir. "'Identifying with the aggressor': From the authoritarian to neoliberal personality." Constellations: An International Journal of Critical and Democratic Theory 25, no. 1 (2018): 147-64. 
Gangl, Manfred. "The Controversy over Friedrich Pollock's State Capitalism." History of the Human Sciences 29, no. 2 (2016): 23-41.

Gasimov, Zaur, and Carl Antonius Lemke Duque, eds. Oswald Spengler als europäisches Phänomen: Der Transfer der Kultur- und Geschichtsmorphologie im Europa der Zwischenkriegszeit 1919-1939. Göttingen: Vandenhoeck \& Ruprecht, 2013.

Gordon, Peter E. Adorno and Existence. Cambridge, MA: Harvard University Press, 2016. Gordon, Peter E. "The Authoritarian Personality Revisited: Reading Adorno in the Age of Trump." In Wendy Brown, Peter E. Gordon, and Max Pensky, Authoritarianism: Three Inquiries in Critical Theory, 45-84. Chicago: University of Chicago Press, 2018.

Jay, Martin. Adorno. Cambridge, MA: Harvard University Press, 1984.

Jay, Martin. The Dialectical Imagination: A History of the Frankfurt School and the Institute of Social Research, 1923-1950. Berkeley: University of California Press, 1996. Habermas, Jürgen. The Theory of Communicative Action. Volume 1: Reason and The Rationalization of Society, translated by Thomas McCarthy. Boston: The MIT Press, 1984.

Herf, Jeffrey. Reactionary Modernism: Technology, Culture, and Politics in Weimar and the Third Reich. Cambridge: Cambridge University Press, 1986.

Hobsbawm, Eric. The Age of Extremes: The Short Twentieth Century 1914-1991. London: Abacus, 1994.

Honneth, Axel. “Anthropologische Berührungspunkte zwischen der lebensphilosophischen Kulturkritik und der 'Dialektik der Aufklärung'”. In 21. Deutscher Soziologentag 1982: Beiträge der Sektions- und ad hoc-Gruppen, edited by Friedrich Heckmann and Peter Winter, 786-92. Opladen: Westdeutscher Verlag, 1983.

Horkheimer, Max. "The End of Reason." Studies in Philosophy and Social Science 9, no. 3 (1941): 366-88.

Horkheimer, Max. "Zur Emanzipation der Philosophie von der Wissenschaft." In Gesammelte Schriften Bd. 10: Nachgelassene Schriften 1914-1931, edited by Alfred Schmidt, 334-419. Frankfurt am Main: Suhrkamp, 1990.

Horkheimer, Max, and Theodor W. Adorno. Dialectic of Enlightenment: Philosophical Fragments, translated by Edmund Jephcott: Stanford, CA: Stanford University Press, 2002. 
Hughes, H. Stuart. Oswald Spengler: A Critical Estimate. New York: Charles Scribner's Sons, 1952.

Hullot-Kentor, Robert. "Foreword: Critique of the Organic." In Theodor W. Adorno, Kierkegaard: Construction of the Aesthetic, translated and edited by Robert HullotKentor, x-xxiii. Minneapolis: University of Minnesota Press, 1989.

Immanen, Mikko. Toward a Concrete Philosophy: Heidegger and the Emergence of the Frankfurt School. Ithaca, NY: Cornell University Press, 2020.

MacWilliams, Matthew C. The Rise of Trump: America's Authoritarian Spring. Amherst, MA: Amherst College Press, 2016.

Mazover, Mark. Dark Continent: Europe's Twentieth Century. New York: Penguin Press, 1998.

Merlio Gilbert, and Daniel Meyer, eds. Spengler ohne Ende: Ein Rezeptionsphänomen im internationalen Kontext. Frankfurt am Main: Peter Lang, 2014.

Michels, Robert. Political Parties: A Sociological Study of the Oligarchical Tendencies of Modern Democracy, translated by Eden and Cedar Paul. New York: Free Press, 1962.

Mörchen, Hermann. Adorno und Heidegger: Untersuchung einer philosophischen Kommunikationsverweigerung. Stuttgart, Klett-Cotta, 1981.

Müller-Doohm, Stefan. Adorno: A Biography, translated by Rodney Livingstone. Cambridge: Polity Press, 2009.

Pensky, Max. "Radical Critique and Late Epistemology: Tocqueville, Adorno, and Authoritarianism." In Wendy Brown, Peter E. Gordon, and Max Pensky, Authoritarianism: Three Inquiries in Critical Theory, 85-124. Chicago: University of Chicago Press, 2018.

Pollock, Friedrich. "State Capitalism: Its Possibilities and Limitations." Studies in Philosophy and Social Science 9, no. 2 (1941): 200-25.

Rabinbach, Anson. In the Shadow of Catastrophe: German Intellectuals between Apocalypse and Enlightenment. Berkeley: University of California Press, 1997.

Riesman, David. The Lonely Crowd: A Study of the Changing American Character. New Haven, CT: Yale University Press, 2001.

Roberts, David. Art and Enlightenment: Aesthetic Theory after Adorno. Lincoln: University of Nebraska Press, 1991. 
Shotwell, James T. "Spengler." In The Faith of an Historian and Other Essays, 221-9. New York: Walker and Company, 1964.

Sombart, Werner. Why Is There No Socialism in the United States, translated by Patricia M. Hocking and C. T. Husbands. London: Macmillan Press, 1976.

"Special Section on Carl Schmitt and the Frankfurt School." Telos 71 (1987): 37-109.

"Special Section on Frankfurt School and Nietzsche." Constellations: An International Journal of Critical and Democratic Theory 8, no. 1 (2001): 127-47.

"Spenglerheft." Logos: Internationale Zeitschrift für Philosophie der Kultur 9, no. 2 (1920/21): 133-295.

Spengler, Oswald. The Decline of the West, Volume I: Form and Actuality, translated by Charles Francis Atkinson. New York: Alfred A. Knopf, 1961.

Spengler, Oswald. The Decline of the West, Volume II: Perspectives of World History, translated by Charles Francis Atkinson. New York: Alfred A. Knopf, 1961.

Spengler, Oswald. Man and Technics: A Contribution to a Philosophy of Life, translated by Charles Francis Atkinson. London: George Allen \& Unwin, 1932.

Stauth, Georg. "Critical Theory and Pre-Fascist Social Thought." History of European Ideas 18, no. 5 (1994): 711-727.

Stone, Ronald H. Professor Reinhold Niebuhr: A Mentor to the Twentieth Century. Louisville, KY: Westminster/John Knox Press, 1992.

Strauss, Leo. "Kurt Riezler." In What Is Political Philosophy? and Other Studies, 233-60. Glencoe, IL: The Free Press, 1959.

Villa, Dana. "Weber and The Frankfurt School." In The Routledge Companion to the Frankfurt School, edited by Peter E. Gordon, Espen Hammer, and Axel Honneth, 266-81. New York: Routledge, 2019.

Weber, Max. "Science as a Vocation." In From Max Weber: Essays in Sociology, translated and edited by H. H. Gerth and C. Wright Mills, 129-56. New York: Oxford University Press, 1958.

Wellmer, Albrecht. The Persistence of Modernity: Essays on Aesthetics, Ethics, and Postmodernism. Cambridge, MA: The MIT Press, 1991.

Wiggershaus, Rolf. The Frankfurt School: Its History, Theories, and Political Significance, translated by Michael Robertson. Cambridge: Polity Press, 1994. 
Wolin, Richard. "Our 'Prophet of Deceit': WWII-era social scientists explained Trump's appeal." The Chronicle of Higher Education, October 30, 2016. www.chronicle.com/article/Our-Prophet-of-Deceit/238176

Wolin, Richard. Walter Benjamin: An Aesthetic of Redemption. New York: Columbia University Press, 1992.

Wolin, Richard. "Walter Benjamin Today." In Labyrinths: Explorations in the Critical History of Ideas, 55-82. Amherst: University of Massachusetts Press, 1995.

Woods, Roger. The Conservative Revolution in the Weimar Republic. New York: Palgrave Macmillan, 1996. 